\title{
Ants (Hymenoptera: Formicidae) of Chelmowa Góra in the Świętokrzyski National Park
}

\author{
Kamil RzESzowski ${ }^{1}$, Hanna BABIK ${ }^{1}$, Wojciech CZECHOwski ${ }^{1}$ and Bálint MARKó ${ }^{2}$ \\ ${ }^{1}$ Museum and Institute of Zoology, Polish Academy of Sciences, Wilcza 64, 00-679 Warsaw, Poland; \\ e-mails:K.Rzeszowski@wp.eu,hbabik@miz.waw.pl,wcz@miz.waw.pl \\ ${ }^{2}$ Department Hungarian Department of Biology and Ecology, Babeş-Bolyai University, Clinicilor str. 5-7, \\ 400006 Chuj-Napoca, Romania; e-mail: mbalint@biolog.ubbchij.ro
}

\begin{abstract}
Species composition, nest densities and ecological profiles of ant communities in three main typical forest habitats of Chełmowa Góra (Chełmowa Mount) in the Świętokrzyski National Park were studied: fertile Carpathian beech forest Dentario glandulosae-Fagetum, subcontinental linden-oak-hornbeam forest Tilio-Carpinetum (marginal zone and interior), continental mixed pine forest Querco roboris-Pinetum (marginal zone and interior). Additionally, a moist rye-grass meadow Arrhenatheretum elatioris adjacent to the mixed pine forest was also surveyed. Nest samples were collected by searching quadrats of different sizes $\left(1 \mathrm{~m}^{2}, 10 \mathrm{~m}^{2}, 100 \mathrm{~m}^{2}\right)$. In total, 16 species were found. Ant communities of the studied habitats differed from each other in their composition, abundance and structure. In respect of nest density, Myrmica ruginodis Nyl. dominated in Tilio-Carpinetum (in both forest zones) and in the interior of Querco roboris-Pinetum, Formica polyctena Först. in the marginal zone of Querco roboris-Pinetum and in Dentario glandulosae-Fagetum, and Lasius niger (L.) in the meadow. The results are discussed in the contexts of the former data from this region, and the possible community-forming impact of the local 'supercolony' of $F$. polyctena
\end{abstract}

Key words: ant communities, community structure, ecological preferences, forests, interspecific competition, Poland, wood ants

\section{INTRODUCTION}

Chełmowa Góra (Mount Chełmowa) is a small (351 $\mathrm{m}$ a.s.1.) single hill within the Świętokrzyskie Mts, situated to the north-east of the range of Łysogóry (Fig. 1). Because of its natural values, already in 1920 a natural reserve was set up here, which constituted the beginnings of the present Świętokrzyski National Park. The local vegetation is diverse due to the complex lie of the land (gorges, depressions). Forests dominate, and they are represented by three main associations: fertile Carpathian beech forest Dentario glandulosae-Fagetum, subcontinental linden-oak-hornbeam forest Tilio-Carpinetum and continental mixed pine forest Querco roboris-Pinetum (formerly Pino-Quercetum; Matuszkiewicz 2007), the two latter diversified into several varieties (see Glazek \& Wolak 1991). Dentario glandulosae-Fagetum covers northern slopes of the hill. The western part (and a small enclave on the north) is overgrown by Tilio-Carpinetum abietetosum, while southern, south-eastern and eastern slopes by Tilio-Carpinetum typicum. Querco roboris-Pinetum occupies flat and slightly sloping central and partly southern parts of the hill.

Originally the natural reserve included the whole area (ca. 163 ha) of Chelmowa Góra. In 1950, when the Świętokrzyski National Park was formed, the strictly protected area was reduced to $13.36 \mathrm{ha}$, which was established for the protection of the Polish larch Larix decidua var. polonica (Raciborski ex Wóycicki) Ostenf. et Syrach (see Zygmunt 1997). This endangered tree variety (formerly recognized as a species and then as a subspecies) was described originally from Chelmowa Góra. Its large and dense concentration, unique in the taxon range, is the main peculiarity of the local flora. On the other hand, one of the local 
faunistic peculiarities is the extremely high number of wood ant (species of the subgenus Formica s. str.) nests, whose impressive mounds and the great abundance of individuals on the forest floor are well-known tourist attraction. Despite these, quite few data are available on the local myrmecofauna.

So far the only systematic study on ants in the Świętokrzyskie Mts is that carried out by Krzysztofiak (1984). Among others, it includes the myrmecofauna of two different habitat types of Chelmowa Gora: the Querco roboris-Pinetum forest and an ecotone between this forest and open habitats. The paper reports 10 ant species from these two habitats of Chelmowa Góra and 23 species from the Świętokrzyskie Mts as a whole, including 22 outdoor species and the synanthropic Monomorium pharaonis (L.). That publication was preceded and followed by some papers including more or less incidental contributions to the myrmecofauna of the region (e.g. Kulmatycki 1920, Pisarski 1961, Krysztofik 1962, Kowalczyk 1988, Liana 2000).

The recent checklist of Polish ants features 47 outdoor species from the whole region of the Świętokrzyskie Mts (Czechowski et al. 2012). However, Strongylognathus testaceus (Schenck) ought to be removed from this list, as it had been included by mistake. This species, allegedly found in Opatów in the Świętokrzyskie Mts - as it was misinterpreted in Catalogue of the fauna of Poland (Pisarski 1975) - was in fact reported from Opatow near Kepno, a village in the Wielkopolsko-Kujawska Lowland (Begdon 1958). This mistake, though noticed by Krzysztofiak (1984), was then repeated in the two subsequent monographs of the ants of Poland (Czechowski et al. 2002, 2012).

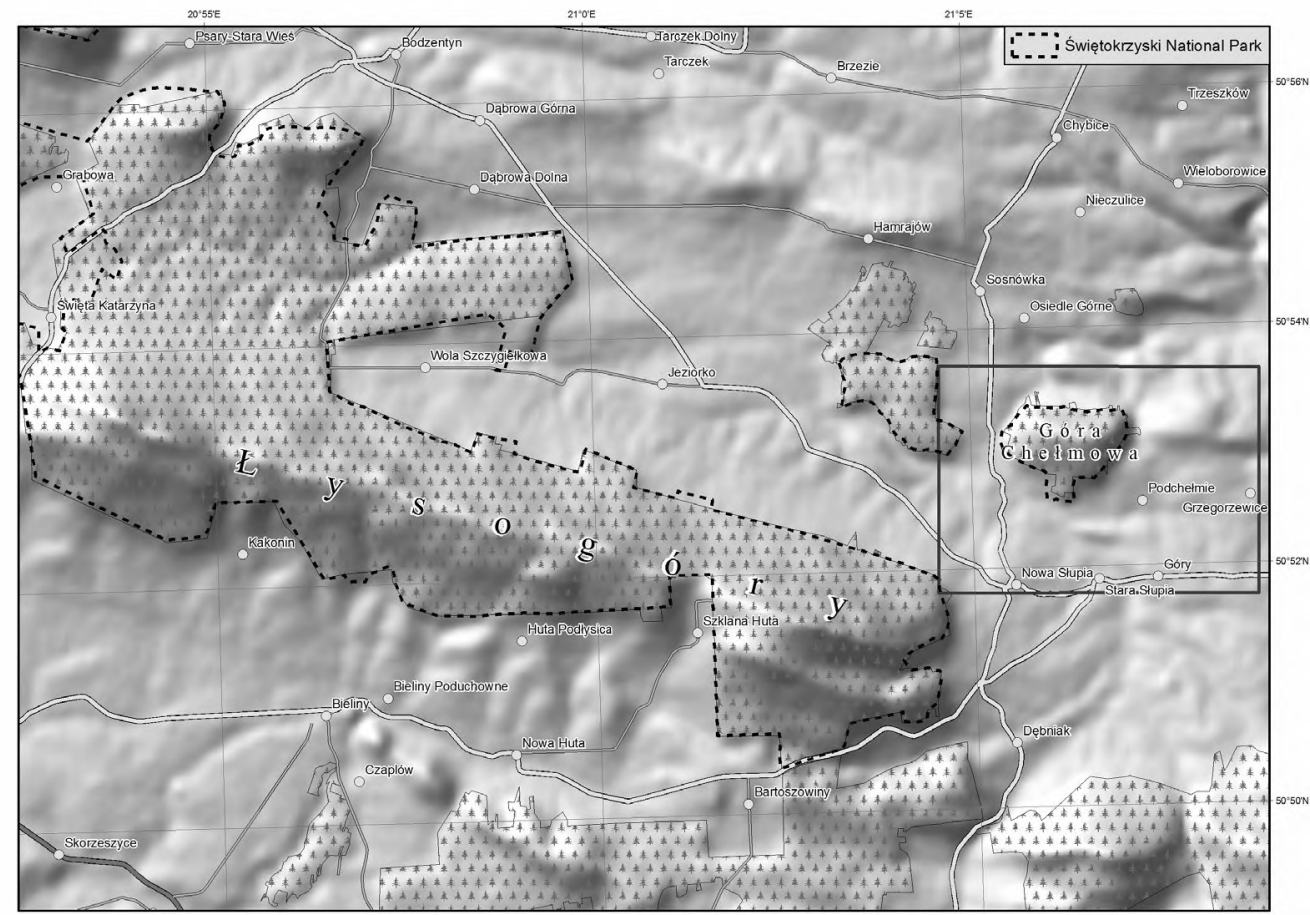

Fig. 1. Location of Chełmowa Góra (Góra Chełmowa) in relation to the compact range of the Świętokrzyski National Park (based on data available from OpenStreetMap, Jarvis et al. 2008 and Generalna Dyrekcja Ochrony Środowiska). 
The aims of the present study are (1) to widen the knowledge on the myrmecofauna of Chelmowa Góra by considering previously not investigated habitats, (2) to investigate the disparity in the structure of ant communities between different local habitats, (3) to check the species identity of the local wood ants due to some doubts concerning their status, and (4) to check the effect of high density of wood ants on co-occurring ant species.

\section{STUDY AREA, METHODS AND MATERIAL}

\section{Habitats and sites}

Investigations were carried out in six sites representing four habitats of the study area, including three forest associations most typical of Chelmowa Gora: fertile Carpathian beech forest (Dentario glandulosae-Fagetum), subcontinental linden-oak-hornbeam forest (TilioCarpinetum) and continental mixed pine forest (Querco roboris-Pinetum) (Fig. 2). In the first case, the forest interior was studied; in the case of the two latter habitats two zones were studied separately: a forest margin zone and the interior part of the forest (ca. $50 \mathrm{~m}$ and $400 \mathrm{~m}$ deep into the forest from the border respectively). Within each habitat a relatively homogenous patch typical of the given plant association was selected. Besides the forests, a moist rye-grass meadow Arrhenatheretum elatioris (formerly Arrhenatheretum medioeuropaeum; Matuszkiewicz 2007) was also studied (Fig. 2). For details regarding the floristic compositions of the forest associations and their possible local differentiation into subassociations and variants see Glazek \& Wolak (1991).

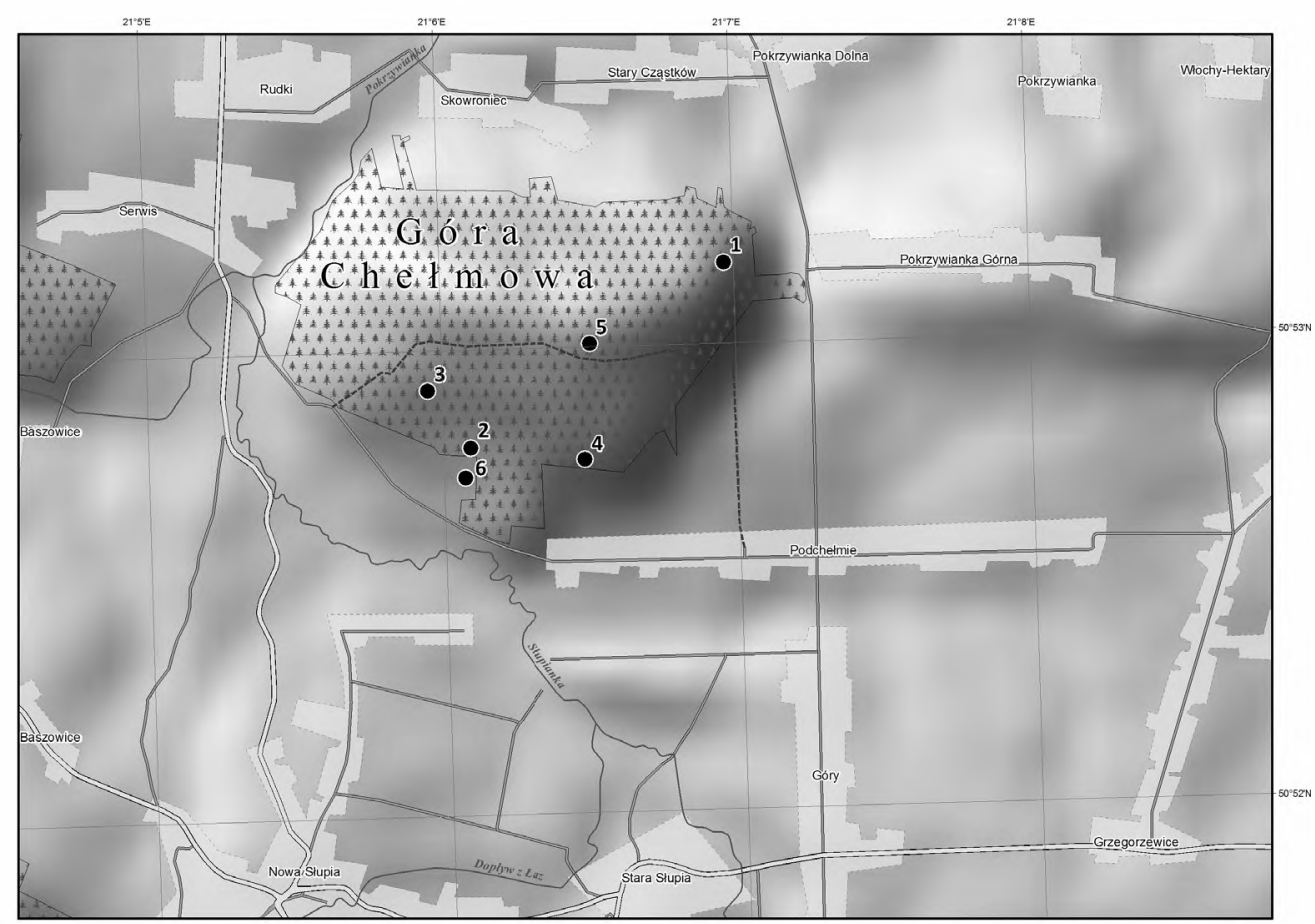

Fig. 2. Locations of the study sites within Chelmowa Góra (Góra Chelmowa): 1 - beech forest, 2 - linden-oakhornbeam forest (forest margin) 3 - linden-oak-hornbeam forest (forest interior), 4 - mixed pine forest (forest margin), 5 -mixed pine forest (forest interior), 6 - moist meadow. 
The studied fertile Carpathian beech forest (site 1) was located on the softly inclined northeastern slope with shallow depressions, near the village of Pokrzywianka Górna. In that place the beech forest bordered the mixed pine forest, and reached almost the foot of the hill. The forest was relatively light and dry (Fig. 3).

The subcontinental linden-oak-hornbeam forest represented the subassociation dominated by fir (Tilio-Carpinetum abietetosum) in a variant with Polish larch. It was situated in the southern part of the hill. Two zones within the forest were studied: a marginal zone (near the tourist track from the village of Nowa Slupia; site 2) and a forest interior (site 3). The terrain in the former was slightly inclined (south-facing), and the forest was rather shady and fairly humid (Fig. 4). The terrain in the latter was slightly convex, and because of that the forest, however even more shaded, was drier (Fig. 5). The tree stands did not differ particularly between the two zones.
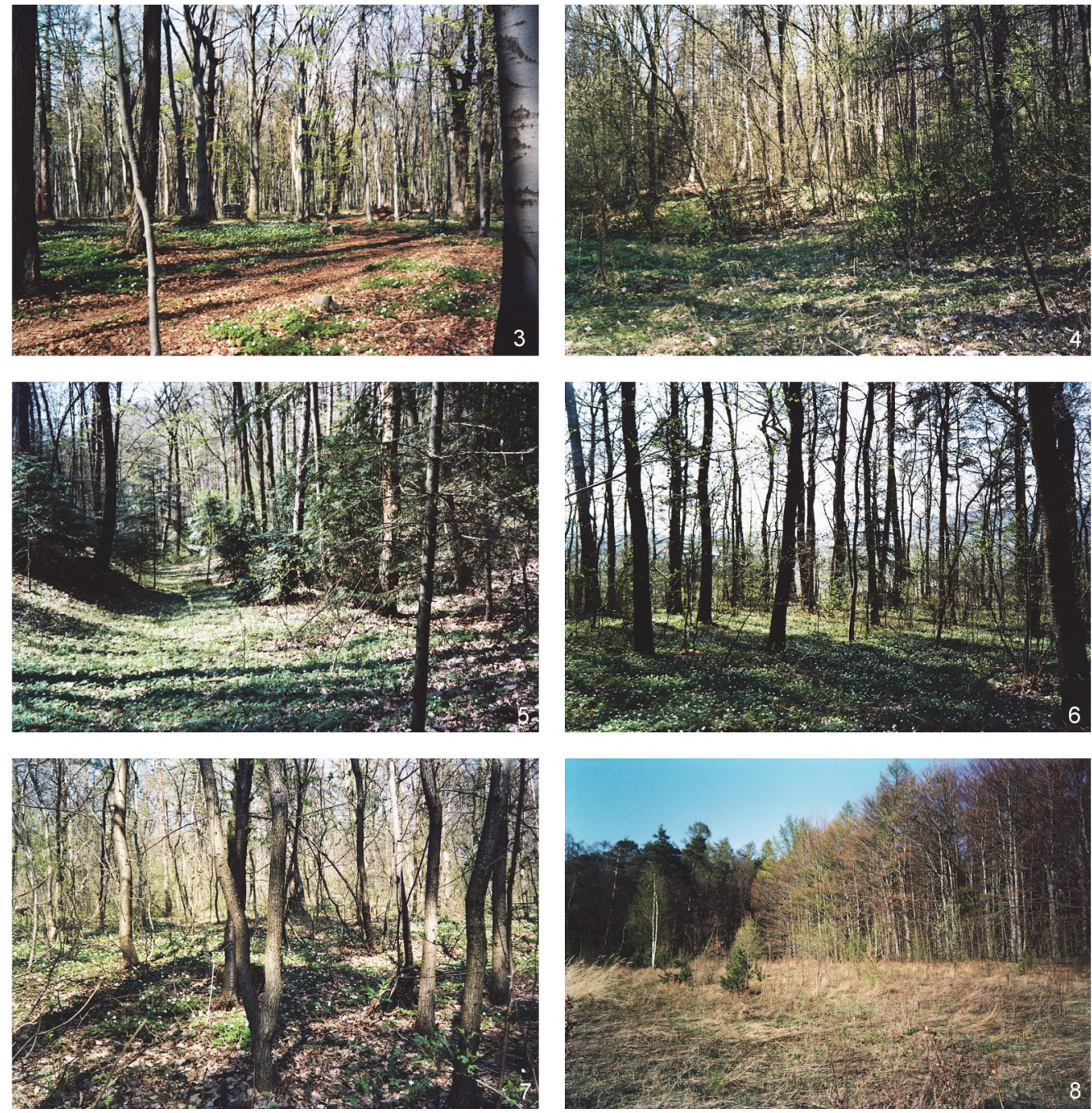

Figs 3-8. Study sites on Chelmowa Góra; 3 - beech forest (site no. 1), 4 and 5 - linden-oak-hornbeam forest: forest margin (site no. 2) and forest interior (site no. 3) respectively, 6 and 7 - mixed pine forest: forest margin (site no. 4) and forest interior (site no. 5) respectively, 8 - moist meadow (site no. 6) (phot. K. Rzeszowski). 
The studied continental mixed pine forest was represented by the association variant with Polish larch. Two zones within the forest were studied: a marginal zone (site 4; Fig. 6) and a forest interior (site 5; Fig. 7), both on the south-facing slope, slightly (especially within the marginal part) descending towards Nowa Slupia. Forest within both zones was equally sunny, fairly dry. Also the vegetation did not vary noticeably between the sites studied.

The moist rye-grass meadow (site 6) was a quite small (about 1.8 ha) area of relatively flat terrain. It bordered the studied linden-oak-hornbeam forest on the north and the mixed pine forest on the east. The study site was situated near the meadow border adjacent to the mixed pine forest (Fig. 8).

\section{Field work and material collected}

Field investigations were carried out in September 2008 and in May and June 2009. Species composition and nest densities were determined by biocoenometric method, i.e. by searching for ant nests in quadrats. According to Pętal \& Pisarski (1966) (see also Pętal \& Pisarski 1981) three size categories of quadrats were applied: $1 \mathrm{~m}^{2}, 10 \mathrm{~m}^{2}$ and $100 \mathrm{~m}^{2}$. Simultaneous use of quadrats of different sizes within a studied habitat is commonly used in myrmecological quantitative research when search accuracy has to be matched to the diverse nesting habits of different species (e.g. Parapura \& Pisarski 1971, Czechowska 1976, Czechowski \& Pisarski 1990, Czechowski et al. 1990, 1995, Gallé 1991, Babik et al. 2009).

In each site 24 small $\left(1 \mathrm{~m}^{2}\right), 20$ medium-sized $\left(10 \mathrm{~m}^{2}\right)$ and 12 large $\left(100 \mathrm{~m}^{2}\right)$ quadrats were set. Therefore, in total, an area of $1424 \mathrm{~m}^{2}$ was searched in each site. Quadrats of each sizecategory were arranged linearly at regular distances, independently of lines of quadrats of the remaining categories. According to principles of the method, quadrats were searched with accuracy inversely proportional to their size. Most thoroughly (centimetre after centimetre) were searched the one-square metre quadrats, which are to detect nests of ants forming small colonies and leading a cryptic mode of life (e.g. Temnothorax spp.). Ten-square metre quadrats, which were searched with moderate accuracy (decimetre after decimetre), are generally used for species forming quite numerous colonies and living in relatively easilydetectable nests (like those of the genera Myrmica Latr., Tetramorium Mayr and Lasius F.). Hundred-square metre quadrats served to estimate nest densities of ants of the genus Formica L. Samples of workers were collected from each ant nest detected. Additionally, in the mixed pine forest samples of nest material were also taken from some wood ants' mounds and sifted in quest for the xenobiotic Formicoxenus nitidulus (Nyl.). In total, 307 nest samples were obtained (not taking into account those of $F$. nitidulus) (Table 1)

In view of a serious divergence (in respect both the species identification and the density of wood ants' nests) between our data and the respective literature data (Krzysztofiak 1984; see Discussion), the area was visited once more in August 2013. On that occasion, a fragment of the local wood ant 'supercolony' was mapped using a Garmin eTrex 30 GPS unit. The fragment included 43 nests located along a ca. $1200 \mathrm{~m}$ long transect through mixed pine forest and linden-oak-hornbeam forest (Fig. 9).

\section{Data analysis}

We assumed that our sampling method delivers estimates of different precision as regards nest densities of various ant species. Therefore, it is necessary to appropriately combine data received from different quadrats in order to obtain the values as accurate as possible (for examples see Czechowski et al. 1995, Babik et al. 2009). To calculate the nest density of a given species, data were used from the size-category of quadrats which was regarded as the most appropriate for that species $\left(1 \mathrm{~m}^{2}-\right.$ Leptothorax spp. and Temnothorax spp.; $10 \mathrm{~m}^{2}-$ Myrmica spp., Tetramorium spp. and Lasius spp.; $100 \mathrm{~m}^{2}-$ Formica spp.), unless the species was recorded from only one other quadrat size-category (see Table 1). 
Table 1. Numbers of nests of particular ant species recorded in the studied habitats and sites; values used for calculation of nest density of the given species are marked with an asterisk.

\begin{tabular}{|c|c|c|c|c|c|c|c|c|c|c|c|c|c|c|c|c|c|c|c|}
\hline \multirow[b]{3}{*}{ No } & \multirow[t]{3}{*}{ Habitat, site and quadrat size } & \multirow{2}{*}{\multicolumn{3}{|c|}{$\begin{array}{c}\text { Beech forest } \\
1 \text { (interior) }\end{array}$}} & \multicolumn{6}{|c|}{ Linden-oak-hornbeam forest } & \multicolumn{6}{|c|}{ Mixed pine forest } & \multirow{2}{*}{\multicolumn{3}{|c|}{$\frac{\text { Moist meadow }}{6}$}} \\
\hline & & & & & \multicolumn{3}{|c|}{2 (margin) } & \multicolumn{3}{|c|}{3 (interior) } & \multicolumn{3}{|c|}{4 (margin) } & \multicolumn{3}{|c|}{5 (interior) } & & & \\
\hline & & $1 \mathrm{~m}^{2}$ & $10 \mathrm{~m}^{2}$ & $100 \mathrm{~m}^{2}$ & $1 \mathrm{~m}^{2}$ & $10 \mathrm{~m}^{2}$ & $100 \mathrm{~m}^{2}$ & $1 \mathrm{~m}^{2}$ & $10 \mathrm{~m}^{2}$ & $100 \mathrm{~m}^{2}$ & $1 \mathrm{~m}^{2}$ & $10 \mathrm{~m}^{2}$ & $100 \mathrm{~m}^{2}$ & $1 \mathrm{~m}^{2}$ & $10 \mathrm{~m}^{2}$ & $100 \mathrm{~m}^{2}$ & $1 \mathrm{~m}^{2}$ & $10 \mathrm{~m}^{2}$ & $100 \mathrm{~m}^{2}$ \\
\hline 1 & Myrmica rubra (L.) & - & - & - & - & - & - & - & - & - & - & - & - & - & - & - & - & $2^{*}$ & 4 \\
\hline 2 & M. ruginodis Nyl. & - & - & $1 *$ & 4 & $13 *$ & 59 & 2 & $9 *$ & 16 & - & - & - & 1 & $1 *$ & - & - & - & $1 *$ \\
\hline 3 & M. rugulosa Nyl. & - & - & - & - & - & - & - & - & - & - & - & - & - & - & - & - & - & $1 *$ \\
\hline 4 & Temnothorax crassispinus (Karav.) & - & - & - & - & - & - & - & - & - & - & - & - & - & - & - & - & - & $1^{*}$ \\
\hline 5 & Tetramorium cf. caespitum (L.) & - & - & - & - & - & - & - & - & - & - & - & $1^{*}$ & - & - & - & - & $1^{*}$ & - \\
\hline 6 & Formica rufa L. & - & - & - & - & - & - & - & - & - & - & - & - & - & - & - & - & - & - \\
\hline 7 & F. polyctena Först. & - & - & $3 *$ & - & - & - & - & - & $2^{*}$ & 1 & 2 & $3^{*}$ & - & 1 & $3 *$ & - & - & - \\
\hline 8 & F. fusca $\mathrm{L}$. & - & - & - & - & - & - & - & - & - & - & - & - & - & - & - & 2 & $3 *$ & 10 \\
\hline 9 & F. cunicularia Latr. & - & - & - & - & - & - & - & - & - & - & - & - & - & - & - & - & 1 & $4^{*}$ \\
\hline 10 & Lasius (Lasius) niger (L.) & - & - & - & - & $1^{*}$ & 12 & 1 & $2 *$ & 7 & - & - & - & - & - & - & 17 & $31 *$ & 68 \\
\hline 11 & L. (Lasius) platythorax Seifert & - & - & - & 2 & $2 *$ & - & - & - & - & - & - & - & - & - & - & - & - & - \\
\hline 12 & L. (Lasius) alienus (Först.) & - & - & - & - & - & - & - & - & - & - & - & $1^{*}$ & - & - & - & - & - & - \\
\hline 13 & L. (Cautolasius) flavus (F.) & - & - & - & - & - & - & - & - & - & - & - & - & - & - & - & 2 & - & $4^{*}$ \\
\hline 14 & L. (Chthonolasius) umbratus (Nyl.) & - & - & - & - & 3* & - & - & - & - & - & - & - & - & - & - & - & - & - \\
\hline 15 & L. (Dendrolasius) fuliginosus & - & - & - & 6 & $2^{*}$ & - & - & - & - & - & - & - & - & - & - & - & - & - \\
\hline \multirow{2}{*}{\multicolumn{2}{|c|}{ Total }} & - & - & 4 & 12 & 21 & 71 & 3 & 11 & 25 & 1 & 2 & 5 & 1 & 2 & 3 & 21 & 36 & 89 \\
\hline & & \multicolumn{3}{|c|}{4} & \multicolumn{3}{|c|}{104} & \multicolumn{3}{|c|}{39} & \multicolumn{3}{|c|}{8} & \multicolumn{3}{|c|}{6} & \multicolumn{3}{|c|}{146} \\
\hline
\end{tabular}


Table 2. Mean nest densities ( $D$ - number of nests per $100 \mathrm{~m}^{2} \pm \mathrm{SD}$ ) and proportions (\%) of particular ant species in the studied habitats and sites ( +- density or proportion close to zero, $x$-species recorded only on the basis of an additional method).

\begin{tabular}{|c|c|c|c|c|c|c|c|c|c|c|c|c|c|}
\hline \multirow[b]{3}{*}{ No } & \multirow[b]{3}{*}{ Species } & \multirow{2}{*}{\multicolumn{2}{|c|}{$\begin{array}{c}\text { Beech forest } \\
1 \text { (interior) }\end{array}$}} & \multicolumn{4}{|c|}{ Linden-oak-hornbeam forest } & \multicolumn{4}{|c|}{ Mixed pine forest } & \multirow{2}{*}{\multicolumn{2}{|c|}{$\frac{\text { Moist meadow }}{6}$}} \\
\hline & & & & \multicolumn{2}{|c|}{2 (margin) } & \multicolumn{2}{|c|}{3 (interior) } & \multicolumn{2}{|c|}{4 (margin) } & \multicolumn{2}{|c|}{5 (interior) } & & \\
\hline & & $D$ & $\%$ & $D$ & $\%$ & $D$ & $\%$ & $D$ & $\%$ & $D$ & $\%$ & $D$ & $\%$ \\
\hline 1 & Myrmica rubra & - & - & - & - & - & - & - & - & - & - & $1.0 \pm 0.31$ & 5.17 \\
\hline 2 & Myrmica ruginodis & $0.08 \pm 0.29$ & 24.24 & $6.5 \pm 0.87$ & 61.91 & $4.5 \pm 0.82$ & 78.95 & - & - & $0.5 \pm 0.22$ & 71.43 & $0.08 \pm 0.29$ & 0.42 \\
\hline 3 & Myrmica rugulosa & - & - & - & - & - & - & - & - & - & - & $0.08 \pm 0.29$ & 0.42 \\
\hline 4 & Formicoxenus nitidulus & - & - & - & - & - & - & $x$ & - & $x$ & - & - & - \\
\hline 5 & Temnothorax crassispimus & - & - & - & - & - & - & - & - & - & - & $0.08 \pm 0.29$ & 0.42 \\
\hline 6 & Tetramorium cf. caespitum & - & - & - & - & - & - & - & - & - & - & $0.5 \pm 0.22$ & 2.58 \\
\hline 7 & Formica rufa & - & - & - & - & - & - & $0.08 \pm 0.29$ & 19.51 & - & - & - & - \\
\hline 8 & Formica polyctena & $0.25 \pm 0.45$ & 75.76 & - & - & $0.2 \pm 0.39$ & 3.51 & $0.25 \pm 0.45$ & 60.96 & $0.2 \pm 0.49$ & 28.57 & - & - \\
\hline 9 & Formica fusca & - & - & - & - & - & - & - & - & - & - & $1.5 \pm 0.37$ & 7.74 \\
\hline 10 & Formica cunicularia & - & - & - & - & $1.0 \pm 0.45$ & 17.54 & - & - & - & - & $0.3 \pm 0.49$ & 1.55 \\
\hline 11 & Lasius niger & - & - & $0.5 \pm 0.22$ & 4.76 & - & - & - & - & - & - & $15.5 \pm 2.11$ & 80.14 \\
\hline 12 & Lasius platythorax & - & - & $1.0 \pm 0.30$ & 9.52 & - & - & - & - & - & - & - & - \\
\hline 13 & Lasius alienus & - & - & - & - & - & - & $0.08 \pm 0.29$ & 19.52 & - & - & - & - \\
\hline 14 & Lasius flavus & - & - & - & - & - & - & - & - & - & - & $0.3 \pm 0.49$ & \\
\hline 15 & Lasius umbraitus & - & - & $1.5 \pm 0.37$ & 14.29 & - & - & - & - & - & - & - & \\
\hline 16 & Lasius fuliginosus & - & - & $1.0 \pm 0.30$ & 9.52 & - & - & - & - & - & - & - & \\
\hline & Total density & \multicolumn{2}{|l|}{0.33} & \multicolumn{2}{|c|}{10.50} & \multicolumn{2}{|c|}{5.70} & \multicolumn{2}{|l|}{0.41} & \multicolumn{2}{|c|}{0.70} & \multicolumn{2}{|c|}{19.34} \\
\hline
\end{tabular}


To obtain total ant nest density, selected data referring to individual species were compiled. The density of nests was expressed as their mean number per $100 \mathrm{~m}^{2}$, similarly like in some previous myrmecofaunistic papers (see Discussion).

In order to compare the ant communities and to characterize their structure some indices commonly used in community ecology were applied. Species compositions were compared using the Sörensen index $(S o)$ of similarity. The Simpson dominance index $(c)$ was used to describe dominance structures, and the Shannon entropy index $(\bar{H})$ was used to estimate species diversity (according to the formula based on $\log _{10}$ ). Ecological characteristics of the species were taken from the recent monograph of the Polish ants by Czechowski et al. (2012).

\section{RESULTS}

In total, 16 ant species were found on Chelmowa Góra (Table 2) but species richness, abundances and interrelations differed considerably between (and even within) individual habitats. Only two species, Formica polyctena (a mound-building wood ant) and Myrmica ruginodis, constituted the ant community of beech forest. Total ant nest density there was the lowest among all the habitats and sites studied $\left(0.33 / 100 \mathrm{~m}^{2}\right.$, Table 2$)$ and characterized by high abundance of $F$. polyctena (more than three fourth of the nests). Both species present here are typical component of the forest myrmecofauna: $F$. polyctena as a rule is a coniferous forest oligotope - however often met also in mixed and deciduous forests - and Myrmica ruginodis is a forest polytope. Not surprisingly then, they were recorded in almost all studied sites, making this community, in general, the most similar to other communities, except of that of the meadow (Table 3). High dis-proportionality in the species' shares was reflected by the high value of the dominance index and low value of the Shannon entropy index (Table 4).

Table 3. Qualitative similarity (Sörensen index; \%) matrix of species composition of ant communities from particular sites (not taking into account Formicoxemus nitidulus).

\begin{tabular}{|l|l|r|r|r|r|r|r|r|}
\hline \multicolumn{1}{|c|}{ Habitat } & \multicolumn{1}{c|}{ Site } & 1 & 2 & 3 & 4 & 5 & 6 & Mean \\
\hline Beech forest & 1 (interior) & - & 40 & 80 & 40 & 100 & 18 & 57 \\
\hline \multirow{2}{*}{ Linden-oak-hornbeam forest } & 2 (margin) & 40 & - & 25 & 0 & 28 & 28 & 24 \\
& 3 (interior) & 80 & 25 & - & 33 & 80 & 33 & 50 \\
\hline \multirow{2}{*}{ Mixed pine forest } & 4 (margin) & 40 & 0 & 33 & - & 40 & 0 & 23 \\
& 5 (interior) & 100 & 28 & 80 & 40 & - & 18 & 53 \\
\hline Moist meadow & 6 & 18 & 28 & 33 & 0 & 18 & - & 19 \\
\hline
\end{tabular}

Table 4. Parameters of structure of ant communities from particular sites: $S$ - number of species, $D$ - nest density (number of nests per $100 \mathrm{~m} 2$ ), $c$ - Simpson index of dominance, $\bar{H}$ - Shannon index of general diversity (based on dat a from the biocoenometric method, i.e. not taking into account Formicoxenus nitidulus).

\begin{tabular}{|l|l|l|c|c|c|}
\hline \multicolumn{1}{|c|}{ Habitat } & \multicolumn{1}{|c|}{ Site } & $S$ & $D$ & $c$ & $\bar{H}$ \\
\hline Beech forest & 1 (interior) & 2 & 0.33 & 0.63 & 0.24 \\
\hline \multirow{2}{*}{ Linden-oak-hornbeam forest } & 2 (margin) & 5 & 10.50 & 0.41 & 0.51 \\
& 3 (interior) & 3 & 5.70 & 0.62 & 0.26 \\
\hline \multirow{2}{*}{ Mixed pine forest } & 4 (margin) & 3 & 0.41 & 0.45 & 0.41 \\
\hline Moist meadow & 5 (interior) & 2 & 0.70 & 0.59 & 0.26 \\
\hline
\end{tabular}

Linden-oak-hornbeam forest was the richest in ants among forest habitats, both in respect of number of species and nest density (Table 2). Seven species occurred there: five in the marginal zone and three in the forest interior. Qualitative similarity between these two local communities was as small as $25 \%$ due to only one common species (Myrmica ruginodis) present (Table 3). Nest density was several times higher than in other forest sites (Table 2) and 
in both forest zones $M$. ruginodis dominated with $62 \%$ and $79 \%$ shares respectively. Besides it (with much lower shares) four Lasius species were found in the marginal zone, and two Formica species (including F. polyctena) in the forest interior (Table 2). Considerable internal differentiation of the myrmecofauna of this forest was reflected in similarities between the individual local communities and those of the other habitats and sites studied. Whereas the community of the forest margin was quite different from the others, that of the forest interior was, in general, fairly similar to them (Table 3). The value of the dominance index of the forest margin community was low due to relatively even distribution of shares of the individual species in the marginal forest zone, the lowest for all the sites studied (Table 4). That, in connection with fairly big number of species, makes this ant community quite diverse: the Shannon entropy index $\bar{H}$ was the highest for all the studied sites (Table 4 ). For the community from the linden-oak-hornbeam interior the index of general entropy is lower, while the index of dominance is higher (Table 4).

Five species (including Formicoxenus nitidulus) were found in the mixed pine forest: four in its marginal zone and three in the forest interior (Table 2). Qualitative similarity between these local communities was $57 \%$, including F. nitidulus, and $40 \%$, excluding it (Table 3 ). Nest densities were generally low, however highly differentiated (contrary to the former habitat; see above and Table 2). In both marginal and interior zones Formica polyctena occurred with quite similar density; however, while it dominated in the margin zone (ca. 61\%), in the forest interior much higher density reached Myrmica ruginodis (equal to ca. $71 \%$ of all nests) (Table 2 ). The situation of the similarities between the single local communities and those of the other habitats and sites resembled that of linden-oak-hombeam forest (see above; Table 3). Values of the dominance index and of the Shannon entropy index $\bar{H}$ of the mixed pine forest ant communities resembled those from the linden-oak-hornbeam forest zones (Table 4).

The meadow ant community was definitely much richer, both in respect of its species composition and nest density, than the forest ones (Table 2). Nine species were reported from there with their total nest density exceeding $19 / 100 \mathrm{~m}^{2}$, i.e. from 1.8 times (linden-oakhornbeam margin) to nearly 59 times (beech forest) higher than respective values of the forest sites. Lasius niger, a polytope of open habitats, constituted more than $80 \%$ of this community (in respect of nest density). Formica fusca and Myrmica rubra, both eurytopic (ubiquitous) species, were relatively abundant (Table 2). As expected, the meadow myrmecofauna was, in general, only to a slight degree similar to those of the forest sites (Table 3). Extremely high predominance of one species resulted in a high dominance index value - the highest among the sites studied. However, due to relatively high number of species, the diversity of this community expressed by the entropy index $\bar{H}$ was not that low (Table 4 ).

Ecological profile of the myrmecofauna of Chelmowa Góra reflected the forest character of the local vegetation (Table 5). More or less strictly forest species, polytopic or oligotopic (Myrmica ruginodis, Formicoxenus nitidulus, Temnothorax crassispinus, Formica rufa, $F$. polyctena, Lasius platythorax, L. fuliginosus) constituted the most numerous group: ca. $44 \%$ of 16 species recorded. Most of other species (37.5\%) were those, which inhabit both forest and open habitats: eurytopes (Myrmica rubra, Formica fusca, Lasius flavus), some specific oligotopes (Tetramorium cf. caespitum, Lasius alienus) and a polytope (L. umbratus). As few as three $(<19 \%)$ were typical open habitats species: Myrmica rugulosa (an oligotope of dry grasslands) and Formica cunicularia and Lasius niger (polytopes of open habitats). Naturally, the classification of species according to their optimal habitat (after Czechowski et al. 2012) cannot rule out a possibility of the presence of 'forest' species in open habitats (like $M$ ruginodis and $T$. crassispinus in moist meadow), and 'typically' open habitat species in forests (like $F$. cunicularia and L. niger in linden-oak-hornbeam forest) (Tables $2 \& 5$ ). 
Table 5. Ecological composition of ant communities in the studied habitats and sites $\left(S-\right.$ number of species, $\%_{D}-$ proportion in total nest number)

\begin{tabular}{|c|c|c|c|c|c|c|c|c|c|c|c|c|}
\hline \multirow[b]{3}{*}{ Ecological category } & \multirow{2}{*}{\multicolumn{2}{|c|}{$\begin{array}{c}\begin{array}{c}\text { Beech } \\
\text { forest }\end{array} \\
1 \\
\end{array}$}} & \multicolumn{4}{|c|}{$\begin{array}{c}\text { Linden-oak-hornbeam } \\
\text { forest }\end{array}$} & \multicolumn{4}{|c|}{ Mixed pine forest } & \multirow{2}{*}{\multicolumn{2}{|c|}{$\begin{array}{c}\begin{array}{c}\text { Moist } \\
\text { meadow }\end{array} \\
6\end{array}$}} \\
\hline & & & & 2 & & 3 & & 4 & & 5 & & \\
\hline & $S$ & $\%_{D}$ & $S$ & $\%_{D}$ & $S$ & $\%_{D}$ & $S$ & $\%_{D}$ & $S$ & $\%_{D}$ & $S$ & $\%_{D}$ \\
\hline Eurytopes (ubiquists) & - & - & - & - & - & - & - & - & - & - & 3 & 14.5 \\
\hline Polytopes of open habitats & - & - & 1 & 4.8 & 1 & 17.5 & - & - & - & - & 2 & 81.7 \\
\hline Polytopes of forests & 1 & 24.2 & 2 & 71.4 & 1 & 79 & - & - & 1 & 71.4 & 1 & 0.4 \\
\hline Polytopes of dry habitats & - & - & - & - & - & - & - & - & - & - & 1 & 2.6 \\
\hline Polytopes of humid habitats & - & - & 1 & 14.3 & - & - & - & - & - & - & - & - \\
\hline Oligotopes of dry grasslands & - & - & - & - & - & - & - & - & - & - & 1 & 0.4 \\
\hline Oligotopes of dry grasslands and forests & - & - & - & - & - & - & 1 & 19.5 & - & - & - & - \\
\hline Oligotopes of deciduous forests & - & - & - & - & - & - & - & - & - & - & - & - \\
\hline Oligotopes of coniferous forests & 1 & 75.8 & 1 & 9.5 & 1 & 3.5 & 2 & 80.5 & 1 & 28.6 & 1 & 0.4 \\
\hline
\end{tabular}

\section{DISCUSSION}

A group of 16 species recorded on Chelmowa Góra during present studies includes the species already known from this place, except Camponotus fallax (Nyl.) and Lasius brunneus (Latr.) (previously found in the ecotone zone; Krzysztofiak 1984). At the same time, eight species are new for Chelmowa Góra: Myrmica rubra, M. rugulosa, Temnothorax crassispinus, Tetramorium cf. caespitum, Formica cunicularia, Lasius platythorax, L. flavus, and $L$. umbratus. Four of them are new for the whole National Park: Myrmica rugulosa, T. crassispinus, and L. platythorax, but none is new for the broader region of the Swietokrzyskie Mts (see Czechowski et al. 2012).

The 'supercolony' of wood ants, for which Chelmowa Góra is famous, stretches within mixed pine forest, beech forest and partly linden-oak-hornbeam forest, thus extending through all main local forest associations. According to the Świętokrzyski National Park's website (www.swietokrzyskipn.org.pl), there are about 500 wood ant mounds on Chelmowa Góra. A serious controversy involving this 'supercolony' arouse concerning both the identity of the wood ant species and its nest density. In the paper of Krzysztofiak (1984), based on studies made at the beginning of 1980s, wood ants occurring in large numbers in the mixed pine forest were identified as Formica rufa, and their nest density was determined as 1.2/25 $\mathrm{m}^{2}$, i.e. 19 times more than now. At the same time $F$. polyctena was then reported from "the ecotone zone" with its nest density six times smaller than that of "F. rufa" (Krzysztofiak 1984). Additionally, the only Myrmica ruginodis nest found in mixed pine forest was situated at $180 \mathrm{~m}$ from the nearest wood ant mound. It means that the real density of the mounds of alleged F. rufa within an area of their concentration must had been even higher, amounting to ca. 6 mounds per $100 \mathrm{~m}^{2}$. It would mean a mound - and quite a big one $(1 \mathrm{~m}$ in diameter and $0.6 \mathrm{~m}$ high on average, some up to $2 \mathrm{~m}$ in diameter and $1 \mathrm{~m}$ high; Krzysztofiak 1984) - every few metres. As the wood ants' workers foraging distance ranges up to $100 \mathrm{~m}$ and more from their nest (Savolainen \& Vepsäläinen 1988, Rosengren \& Sundström 1991, Vepsäläinen \& Savolainen 1994, Sorvari 2009) and F. rufa is a highly aggressive territorial species, such nest density is virtually possible only for polygynous colonies forming polydomous societies. Although there are reports of polygynous F. rufa in Europe (e.g. Dekonninck et al. 2010, A. Mabelis, pers. obs.), the species in continental Eurasia is considered, in principle, monogynous (Collingwood 1979, Seifert 1991a) and then usually monodomous. On the other hand, closely related $F$. polyctena is largely renowned for its high density polydomous colonies (so-called supercolonies). 
Already in early 2000s, W. Czechowski received from the Świętokrzyski National Park a few nest samples of wood ants, collected in mixed pine forest on Chelmowa Góra. All of them represented typical Formica polyctena. Efforts made in order to get the proof materials of the former study (Krzysztofiak 1984) were unsuccessful: most probably the samples had been lost. Thus the problem of the divergence between the old literature data and the actual state (including the incredibly high, even for $F$. polyctena, previous data on mound density) remains unsolvable and any speculations seem to be futile. The recent studies confirmed the species status of the wood ant that forms the 'supercolony' under discussion: it is definitely $F$. polyctena. However its single nests are not so densely distributed as it was reported for Krzysztofiak's (1984) "F. rufa" (Fig. 9). Formica rufa is also present on Chelmowa Góra; it was reported only from the marginal zone of mixed pine forest, where it co-occurs with $F$. polyctena, however much less abundantly.

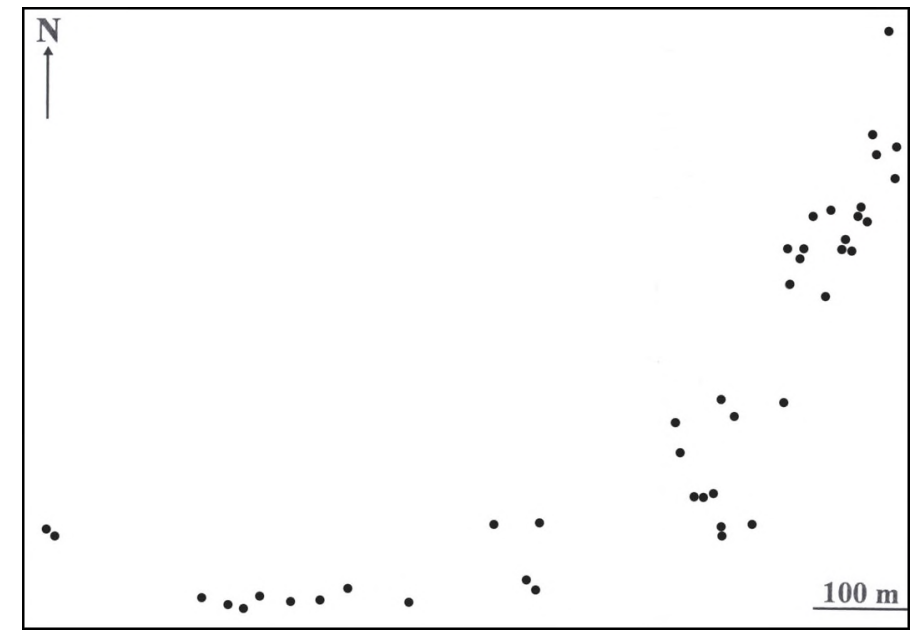

Fig. 9. A map of a fragment of the $F$. polyctena 'supercolony' along the track through mixed pine forest and partly linden-oak-hornbeam forest (left bottom part) on Chelmowa Góra (only nests visible from the track are marked).

Ant communities are organized hierarchically: high ranked species outcompete lower ranked ones (see Cerdá et al. 2013). In the north cold temperate forest zone the following main competitive levels of ant species are distinguished (from top to bottom): (1) territorial species able to maintain around-nest territories, i.e. defending their whole foraging areas; (2) encounter species able to defend their food sources; (3) submissive species, which defend only their nests (Vepsäläinen \& Pisarski 1982, Savolainen \& Vepsäläinen 1988). Top dominants include wood ants of the subgenus Formica s. str., and especially species of the Formica rufa-group (e.g. F. polyctena and F. rufa), well-known for their restrictive impact on lower-ranked species (Mabelis 1984, Pisarski \& Vepsäläinen 1989, Savolainen \& Vepsäläinen 1989, Savolainen et al. 1989, Punttila et al. 1991). The community-structuring role of these species can be revealed, when ant communities with and without them are analyzed - as e.g. in the case of our sites and eventually compared to other forest ant communities in Poland.

On Chelmowa Góra these forest ant communities, which included wood ants, were especially poor in respects of their species compositions and nest densities. Besides the very wood ants (Formica polyctena, F. rufa), and not counting their social parasite (xenobiont) Formicoxenus nitidulus, they consisted of only one (beech forest) or two (mixed pine forest and interior part of linden-oak-hornbeam forest) other species with low nest densities (Table 2). 
In contrast, the ant community of free of wood ants marginal part of linden-oak-hornbeam forest was much richer in species and nests. Similar picture, suggesting strong communityforming role of wood ants, emerges from Krzysztofiak's (1984) data. Besides mixed pine forest on Chelmowa Góra, dominated by wood ants, two other forest habitats of the Świętokrzyski National Park were studied by this author - both without wood ants. As many as six ant species occurred in each of these two latter forests, with their total nest densities 79 (fertile Carpathian beech forest) and 84 (upland mixed fir forest Abietetum polonicum) times higher than that of Myrmica rugulosa - the only species co-occurring with wood ants - in mixed pine forest. The nest densities of $M$. rugulosa were 3.3 and 8.3 times higher in these wood-antless forests, respectively, than in the wood-ant right mixed pine forest (Krzysztofiak 1984).

Differences discussed above reveal themselves even more distinctively, when the ant communities from Chelmowa Góra forests occupied by the Formica polyctena 'supercolony' are compared with communities of similar (in respect of phytosociology and age) forests in Poland. As regards Querco roboris-Pinetum (continental mixed pine forest) literature data on the ant nest density are available only for one forest of the same association in the Kampinoski National Park (Babik et al. 2009), and three subcontinental moist pine forests (PeucedanoPinetum) of the same alliance (Dicrano-Pinion; see Matuszkiewicz 2007), i.e. those in the Białowieska Forest, the Biała Forest and the Tucholskie Forests (Czechowski et al. 1995; see also Czechowski \& Czechowska 2006). There were ca. 2-4 times more ant species present in these four compared forests (considering only mature and matured tree stands with no or at most scarce wood ants present), and their total nest densities were from 39 to nearly 300 times higher than in mixed pine forest on Chelmowa Góra (including Formica polyctena in the latter).

According to literature data based on nest density, ant communities of Polish subcontinental linden-oak-hornbeam forests (Tilio-Carpinetum) are much poorer, both qualitatively and quantitatively, than those in pine forests. Comparative literature data come from four nature reserves ("Dębina" ad Klembów, "Modrzewina" ad Belsk Duży, "Cyganka" in the Kampinoska Forest, and the Jaktorowska Forest) without wood ants (Czechowski \& Pisarski 1990). Compared to these forests, the ant community of linden-oak-hornbeam forest on Chelmowa Góra is relatively rich (Table 2), and possible restrictive impact of the local Formica polyctena 'supercolony' is less explicit than in the case of mixed pine forest. Distinctly richer than the community with $F$. polyctena on Chelmowa Góra was the community of only one of the comparative wood-antless forests ("Dębina"; four species vs. two species besides $F$. polyctena and 11.3 nests per $100 \mathrm{~m}^{2}$ vs. $5.7 / 100 \mathrm{~m}^{2}$, respectively). Another lindenoak-hornbeam forest ("Cyganka") was admittedly three times richer in species, but a bit poorer in respect of the nest density $\left(4 / 100 \mathrm{~m}^{2}\right)$. The remaining two forests had the equal numbers of species (two), and smaller nest densities $\left(1.3 / 100 \mathrm{~m}^{2}\right.$ and $\left.1.9 / 100 \mathrm{~m}^{2}\right)($ Czechowski \& Pisarski 1990) than the wood-antright community on Chelmowa Góra (Table 2). Additionally, two of the comparative communities included Lasius niger sensu Linnaeus (Czechowski \& Pisarski 1990). So, it cannot be excluded that in fact one of them or both consisted of one species more, as the data have not been reassessed (unlike it has been done for moist pine forests; Czechowski \& Czechowska 2006) after Seifert's (1991b) splitting of the 'old' Lasius niger into two species.

As for fertile Carpathian beech forest (Dentario glandulosae-Fagetum) available are data on only one quantitatively studied forest of the same association in the Bieszczady Mts (Parapura \& Pisarski 1971, Pisarski 1971) and two forests of the same alliance (Fagion sylvaticae; see Matuszkiewicz 2007) in Pomerania studied in 'semi-quantitative' way (fertile lowland beech forest Galio odorati-Fagetum and acidophilic lowland beech forest Luzulo pilosae-Fagetum; 
Wlodarczyk 2010). The forest in the Bieszczady Mts was, unlike that on Chelmowa Góra (see Fig. 3), quite humid and very shady, and in result - totally antless. On the other hand, the two Pomeranian forests ant communities - first with Formica rufa scarcely present and second with wood ants lacking - were seven and 3.5 times richer in species, respectively, than the community dominated by $F$. polyctena on Chelmowa Góra.

To sum up, the diversity of ants in forests of Chelmowa Góra is rather low. It concerns individual communities (nest densities are generally low and the species compositions poor), as well as the whole local forest myrmecofauna (13 species altogether in three different forest associations). In the light of the above discussion and despite some ambiguity, such situation may be ascribed to the presence of the huge Formica polyctena 'supercolony' and strong competitive pressure of these ants towards other ant species. Other explanations, like specific unfavorable conditions, seems less plausible. For example, all forests studied, except fertile beech forest, were situated on the south and south-east inclination of a slope (Fig. 2), which are more suitable for nesting than e.g. north-east inclinations. On the other hand, the beech forest on Chelmowa Góra is of fertile type, thus assumptions that it was less favorable for ants (because of poor soil type) than other beech forests in Poland, is also unlikely.

In the nature of things, the ant community of moist meadow (Arrhenatheretum elatioris) on Chełmowa Góra did not include wood ants nesting there (however, it cannot be ruled out that workers from nearby mixed pine forest entered the meadow). The meadow, with its ant nest density of ca. $19 / 100 \mathrm{~m}^{2}$ felt well into a range typical of other Polish meadows of this type (4$36 / 100 \mathrm{~m}^{2}$, mean $22.5 / 100 \mathrm{~m}^{2}$ ), and in respect of the species richness ( 9 species) it even exceeded them (1-7 species; according to Pętal et al. 1970, Pętal 1980, Czechowski et al. 1990).

\section{ACKNOWLEDGEMENTS}

We thank Management of the Świętokrzyski National Park for the license to carry out research in the protected area of Chelmowa Góra. We are also grateful to Marcin Gasior (a GIS specialist in the Museum and Institute of Zoology, PAS) for the preparation of maps (Figs 1 and 2). The critical remarks and suggestions of three reviewers on earlier versions of the manuscript contributed essentially to its improvement.

\section{REFERENCES}

BABIK H. , CZECHOWSKi W., WŁodARCZyK T. \& STERzyŃsKa M. 2009. How does a strip of clearing affect the forest community of ants (Hymenoptera: Formicidae). Fragmenta Faunistica 52: 125-141.

BEGDON J. 1958. Nowe stanowiska kilku interesujących gatunków Formicoidea w Polsce. Annales Universitatis Mariae Curie-Skłodowska, C 13: 85-93.

CERDÁ X., ARNAN X. \& RETANA J. 2013. Is competition a significant hallmark of ant (Hymenoptera: Formicidae) ecology? Myrmecological News 18: 131-147.

Collingwood C. A. 1979. The Formicidae (Hymenoptera) of Fennoscandia and Denmark. Fauna Entomologica Scandinavica 8: 1-174.

CzEchowska W. 1976. Myrmekofauna Pienińskiego Parku Narodowego (Hymenoptera, Formicoidea). Fragmenta Faunistica 21: 115-144.

CZECHOWSKI W. \& CZECHOWSKA W. 2006. Succession of Lasius s. str. ant species (Hymenoptera: Formicidae) in moist pine forests - reassessment after taxonomic revisions of the subgenus. Fragmenta Faunistica 49: 91-97.

CZECHOWSKI W. \& PISARSKI B. 1990. Ants (Hymenoptera, Formicoidea) of linden-oak-hornbeam forests and thermophilous oak forests of the Mazovian Lowland. 1. Nest density. Fragmenta Faunistica 34: 133-141.

CZECHOWSKI W., PISARSKI B. \& CZECHOWSKA W. 1990. Ants (Hymenoptera, Formicoidea) of moist meadows on the Mazovian Lowland. Fragmenta Faunistica 34: 47-60.

CzEChOWSKI W., PISARSKI B. \& YAMAUCHI K. 1995. Succession of ant communities (Hymenoptera, Formicidae) in moist pine forests. Fragmenta Faunistica 38: 447-488.

CZECHOWSKI W., RADCHENKO A. \& CZECHOWSKA W. 2002. The ants (Hymenoptera, Formicidae) of Poland. Museum and Institute of Zoology PAS, Warszawa, $200 \mathrm{pp}$.

CZECHOWSKI W., RADCHENKO A., CZECHOWSKA W. \& VEPSÄLÄnNEN K. 2012. The ants of Poland with reference to the myrmecofauna of Europe. Fauna Poloniae 4 (ns), Natura optima dux Foundation, Warszawa, 496 pp. 
DEKONINCK W., HENDRICK F., GRoOTAERT P. \& MAELFAIT J.-P. 2010. Present conservation status of red wood ants in north-western Belgium: worse than previously, but not a lost cause. European Journal of Entomology 107: 209-218.

GALLE L. 1991. Structure and succession of ant assemblages in a north European sand dune area. Holarctic Ecology 14: 31-37.

GENERALNA DYREKCJA OCHRONY ŚRODOWISKA: http://www.geoserwis.gdos.gov.pl.

GLAZEK T. \& WOLAK J. 1991. Zbiorowiska roślinne Świętokrzyskiego Parku Narodowego i jego strefy ochronnej. Monographiae Botanicae 72: 3-108.

JARVIS A., REUTER H. I., NELSON A. \& GUEVARA E. 2008. Hole-filled seamless SRTM data V4, International Centre for Tropical Agriculture (CIAT), available from http://srtm.csi.cgiar.org.

KOWALCZYK A. 1988. Nowe stanowiska w Polsce interesujących gatunków żądłówek Hymenoptera, Aculeata. Przegląd Zoologiczny 32: 221-223.

LianA A. 2000. Bezkręgowce lądowe. In: CIEŚLnjski S. \& KowAlKowsKi A. (eds), Monografia Świętokrzyskiego Parku Narodowego, Swiętokrzyski Park Narodowy, Bodzentyn, pp. 309-328.

KRYSZTOFIK E. 1962. Inwentaryzacja mrowisk w uroczyskach Świętokrzyskiego Parku Narodowego. Las Polski 36: 9-11.

KRZYSZTOFIAK L. 1984. Mrówki (Hymenoptera, Formicoidea) Świętokrzyskiego Parku Narodowego. Fragmenta Faunistica 28: 309-323.

KULMATYCKI W. 1920. Mrówki niektórych okolic Malopolski. Sprawozdanie Komisji Fizjograficznej 53/54: 157-172.

MABELIS A. A. 1984. Interference between wood ants and other ant species (Hymenoptera, Formicidae). Netherlands Journal of Zoology 34: 1-20.

Matuszkiewicz W. 2007. Przewodnik do oznaczania zbiorowisk roślinnych Polski. Państwowe Wydawnictwo Naukowe, Warszawa, 537 pp.

OPENSTREETMAP. http://www.openstreetmap.org.

PARAPURA E. \& PISARSKI B. 1971. Mrówki (Hymenoptera, Formicidae) Bieszczadów. Fragmenta Faunistica 17: 319-356.

PęTAL J. 1980. Ant populations, their regulation and effect on soil in meadows. Ekologia Polska 28: 297-326.

PĘTAL J., JAKUBCZYK H. \& WóJCIK Z. 1970. Influence des fourmis sur les modifications des sols et des plantes dans les milieux de prairie. In: PHLLLIPSON J. (ed.), Methods of study in soil ecology. UNESCO, Paris, pp. 235-240.

PĘTAL J. \& PISARSKI B. 1966. Metody ilościowe stosowane w badaniach myrmekologicznych. Ekologia Polska, B 12: $363-376$.

PĘTAL J. \& PisARSKi B. 1981. Formicidae. In: GóRNY M. \& GRÜM L. (eds), Metody stosowane w zoologii gleby. Państwowe Wydawnictwo Naukowe, Warszawa, pp. 264-275

PISARSKI B. 1961. Studien über die polnischen Arten der Gattung Camponotus Mayr (Hymenoptera, Formicidae). Annales Zoologici 9: 147-208.

PISARSKI B. 1971. Charakterystyka zoologiczna środowisk Bieszczadów Zachodnich. Fragmenta Faunistica 17: 24-30.

PISARSKI B. 1975. Mrówki. Formicoidea. Katalog Fauny Polski (no 23) 26, 1, 85 pp.

PISARSKI B. \& VEPSÄLÄINEN K. 1989. Competition hierarchies in ant communities (Hymenoptera, Formicidae). Annales Zoologici 42: 321-328.

PUnTtLA P., HAila Y., PAJUNEN T. \& TUKIA H. 1991. Colonisation of clearcult forests by ants in southern Finland: a quantitative survey. Oikos 61: 250-262.

ROSENGREN R. \& SUNDSTRÖM L. 1991. The interaction between red wood ants, Cinara aphids, and pines. A ghost of mutualism past? In: HUXLEY C. R. \& CUTLER D. F. (eds), Ant-plant interactions. Oxford University Press, Oxford, pp. $80-91$.

SAVOLAINEN R. \& VEPSÄLÄINEN K. 1988. A competition hierarchy among boreal ants: impact on resource partitioning and community structure. Oikos 51: 135-155.

SAVOLAINEN R. \& VEPSÄLÄINEN K. 1989. Niche differentiation of ant species within territories of the wood ant Formica polyctena. Oikos 56:3-16.

SAVOLAINEN R., VEPSÄLÄINEN K. \& WUORENRINNE H. 1989. Ant assemblages in the taiga biome: testing the role of territorial wood ants. Oecologia 81: 481-486.

SEIFERT B. 1991a. The phenotypes of the Formica rufa complex in East Germany. Abhandlungen und Berichte des Naturkundemuseums Görlitz 65: 1-27.

SEIFERT B. 1991b. Lasius platythorax n. sp., a widespread sibling species of Lasius niger (Hymenoptera: Formicidae). Entomologia Generalis 16: 69-81.

SORVARI J. 2009. Foraging distances and potentiality in forest pest insect control: an example with two candidate ants. Myrmecological News 12: 211-215.

ŚWIETOKRZYSKI NATIONAL PARK: http://www.swietokrzyskipn.org.pl.

VEPSÄLÄINEN K. \& PISARSKI B. 1982. Assembly of island ant communities. Annales Zoologici Fennici 19: 327-335.

VEPSÄLÄINEN K. \& SAVOLAINEN R. 1994. Ant-aphid interaction and territorial dynamics of wood ants. Memorabilia Zoologica 48: 251-259.

WLODARCZYK T. 2010. Ant species composition in relation to forest associations in Szczecin Landscape Park. Polish Journal of Entomology 79: 91-99.

ZYGMUNT R. 1997. Liczba kształtu modrzewia polskiego w rezerwacie ścisłym na Górze Chełmowej. Sylwan 141(11): 83-90. 


\section{STRESZCZENIE}

\section{[Mrówki (Hymenoptera: Formicidae) Chelmowej Góry w Świętokrzyskim Parku Narodowym]}

Badano skład gatunkowy i zagęszczenie gniazd mrówek w typowych środowiskach leśnych obszaru ochrony ścislej „Chelmowa Góra” (enklawy Świętokrzyskiego Parku Narodowego): żyznej buczyny karpackiej (Dentario glandulosae-Fagetum), subkontynentalnego gradu (TilioCarpinetum) i kontynentalnego boru mieszanego (Querco roboris-Pinetum) oraz dodatkowo świeżej lakki rajgrasowej (Arrhenatheretum elatioris). W grądzie i borze wzięto pod uwage po dwie strefy leśne: brzeżna strefę lasu i wnętrze lasu. Materiał w postaci prób gniazdowych zbierano biocenometryczna metoda przeszukiwania kwadratów o powierzchni $1 \mathrm{~m}^{2}, 10 \mathrm{~m}^{2}$, $100 \mathrm{~m}^{2}$. Łącznie znaleziono 16 gatunków mrówek. Zgrupowania z poszczególnych środowisk liczyly od dwóch (w buczynie) do dziewięciu (na lące) gatunków. Zagęszczenie gniazd bylo wysoce zróżnicowane: od $0,33 / 100 \mathrm{~m}^{2}$ w buczynie do $19,34 / 100 \mathrm{~m}^{2}$ na lące. Najliczniejszymi (pod względem zagęszczenia gniazd) gatunkami w poszczególnych środowiskach byly: Formica polyctena Först. (leśny oligotop) w buczynie i brzeżnej partii boru, Myrmica ruginodis (leśny politop) w grądzie (obu strefach) i wnętrzu boru oraz Lasius niger (L.) (politop terenów otwartych) na lace. Formica polyctena tworzy na Chelmowej Górze (w borze mieszanym, buczynie i grądzie) tzw. superkolonię liczącą setki gniazd. Występujące w dużym zagęszczeniu gniazda i, co za tym idzie, ogromna liczebność mrówek, należą do osobliwości tego obszaru. Jak wszystkie rude mrówki leśne, $F$. polyctena jest gatunkiem terytorialnym, zajmujacym szczytowe miejsce w międzygatunkowej hierarchii konkurencyjnej. W tym kontekście wyniki uzyskane na Chelmowej Górze przedyskutowano pod katem ograniczajaccego wplywu tamtejszej superkolonii na występowanie pozostalych gatunków mrówek, a tym samym różnorodność ich miejscowych zgrupowań. 